of the British Consulate, which was still in existence. Then suddenly I received a summons to the Ministry of Foreign Affairs, which I instantly obeyed, only to learn that I was under strict orders to abandon all attempts at correspondence with an 'enemy alien', whoever it might be, until the conclusion of hostilities, if I did not want to expose myself to consequences quite as unpleasant as anything I would be causing the recipient of my letters.

\title{
A Friendship Broken
}

\section{DORIS JONES}

From Doris Arthur Jones, The Life and Letters of Henry Arthur Jones (London: Victor Gollancz, 1930) p. 310. Jones was to play a leading role in Shaw's expulsion from the Dramatists' Club in the autumn of 1915, on account of his attitude to the war. He continued to attack him long after the war was over, despite Shaw's refusal to take offence.

My father's friendship with Shaw was one of the most delightful and cordial of all his many friendships. He had for Shaw a deep and strong attachment, and for more than twenty years GBS's companionship and their intercourse had been a constant pleasure and stimulation to him. He often referred to the times when GBS was a journalist and used to stay with him. But soon after the War broke out Henry Arthur was amazed and disgusted at GBS's attitude. Writing to me from New York in 1914, he said: 'Shaw continues his crazy attacks. I never felt more angry with any man. He is trying to keep up the strife between England and Ireland. I do not think I can meet him in the future.' In 1915 he wrote: 'No use talking or thinking about the War. It's awful, and Shaw is only anxious to get an advertisement out of it.'

$\mathrm{He}$ felt that Wells and Shaw were the spokesmen of the most dangerous and fallacious political creeds, and that it was his duty as a patriot to combat their influence with every means at his disposal. He was nourished and sustained in this conviction by the enormous body of approval and encouragement he received from all over the world. A great many prominent English men and women supported him in his campaign, and he received hundreds of letters from unknown correspondents, who thanked him for the public service he was rendering England. 